\title{
Optic Chiasm
}

National Cancer Institute

\section{Source}

National Cancer Institute. Optic Chiasm. NCI Thesaurus. Code C90609.

An anatomic structure formed by the crossing of the two optic nerves under the hypothalamus. 